Studia Philosophiae Christianae

UKSW

$51(2015) 4$

\title{
PIOTR ŁACIAK
}

\section{POJĘCIE PRZESĄDU W FILOZOFII KRYTYCZNEJ KANTA I FENOMENOLOGII HUSSERLA}

\begin{abstract}
Streszczenie. W artykule poddano badaniu pojęcie przesądu w teoriach Kanta i Husserla. Według Kanta, przesądy należy odróżnić od sądów tymczasowych, które można nazwać antycypacjami lub maksymami wszelkiego badania. Wydajemy sąd tymczasowy o jakiejś rzeczy, zanim poznamy ją za pomocą sądu określającego. Z kolei przesądy są sądami tymczasowymi (lub mniemaniami) błędnie uznanymi za sądy określające, to znaczy sądami, które przyjmujemy jako zasady bez badania warunków ich prawdziwości. Kanta pojęcie przesądu ma zatem konotacje negatywne a celem filozofii krytycznej jest przezwyciężenie wszelkich przesądów. W przeciwieństwie do Kanta, Husserl rozróżnia przesądy pozytywne i negatywne: pozytywny przesąd jest rozumiany jako przed-sąd w formie presumpcyjnej przedwiedzy i odpowiada Kantowskiemu pojęciu antycypacji, która jest właściwa sądowi tymczasowemu, podczas gdy obiektywistyczna (naturalistyczna) naiwność okazuje się przesądem negatywnym. Celem fenomenologii jest zawieszenie wszystkich przesądów i to zawieszenie umożliwia badanie ich źródeł. W artykule autor wykazuje, że Husserlowska koncepcja przesądu jako przed-sądu jest analogiczna do Gadamerowskiej rehabilitacji przesądów jako przed-rozumienia. Dlatego też można wskazać podobieństwa między Kanta pojęciem sądu tymczasowego, Husserla ideą przedwiedzy i Gadamera koncepcją przed-rozumienia.
\end{abstract}

Słowa kluczowe: Immanuel Kant, Edmund Husserl, Hans-Georg Gadamer, przesąd, przed-sąd, sąd tymczasowy, przedwiedza, przed-rozumienie

1. Kanta pojęcie przesądu: przesąd jako sąd tymczasowy błędnie uznany za sąd określający. 2. Husserla pojęcie przesądu: przesąd jako niejasność zrozumiała sama przez się. 3. Hermeneutyczne implikacje krytyki przesądów.

Piotr Laciak

piotr.laciak@us.edu.pl
Uniwersytet Śląski w Katowicach, Instytut Filozofii Bankowa 11, 40-007 Katowice 
Celem artykułu jest wykazanie analogii między koncepcjami Immanuela Kanta i Edmunda Husserla w świetle Gadamerowskiej rehabilitacji przesądów. W literaturze przedmiotu zazwyczaj akcentuje się różnicę między tymi filozofami we wskazanym aspekcie, uznając rehabilitację przesądów za hasło hermeneutyki Hansa-Georga Gadamera, która dystansuje się zarówno od oświeceniowej dyskredytacji przesądów (kulminującej w filozofii Kanta), jak i od fenomenologicznego ideału bezzałożeniowości poznania (Husserl). Różnica między Kantem, Husserlem i Gadamerem w odniesieniu do rehabilitacji przesądów straci jednak na ostrości, gdy odstąpimy od literalnych rozbieżności między prezentowanymi przez tych myślicieli wykładniami przesądów i dokonamy ich analizy rzeczowej, eksponującej wewnętrzny związek pojęcia przesądu z pojęciami presumpcji, mniemania, sądu tymczasowego, przedwiedzy i przed-rozumienia. To właśnie dostrzeżenie takiego związku umożliwia rozpoznanie zasadniczej analogii między tymi wykładniami tam, gdzie jej się nie zauważa. Dlatego dalszym celem artykułu jest ujawnienie niejednoznaczności pojęcia przesądu, niejednoznaczności, która otwiera nowe historycznofilozoficzne perspektywy interpretacyjne, skutkujące zarazem epistemologicznymi rozstrzygnięciami, jako że problem uwikłania poznania w przesądy sprowadza się w istocie do problemu założeniowości poznania, to znaczy - w języku omawianych koncepcji - problemu współzależności między tym, co presumpcyjnie antycypowane, i tym, co dane, współzależności oznaczającej, że - w terminologii koła hermeneutycznego - poznanie zaczyna się od mniemania, a mniemanie wymaga potwierdzenia w dalszym przebiegu poznania. Postawienie problemu przesądów ma również istotne znaczenie dla właściwego zrozumienia transcendentalizmu Kanta i Husserla jako krytyki poznania, posługującej się metodą zawieszenia sądów czy przeświadczeń, ponieważ pozwala uznać owo zawieszenie za zawieszenie chwilowe, umożliwiające badanie źródeł i granic poznania.

Werner Schneiders zwracając uwagę na niejednoznaczność pojęcia przesądu, zauważa, że oscyluje ono między dwoma znaczeniami: 
prawniczym i filozoficznym ${ }^{1}$. Pojęcie przesądu (niem. Vorurteil, fr. préjugé, ang. prejudice) sięga tradycji rzymskiej jurysdykcji i stanowi odpowiednik łacińskiego praejudicium. Praejudicium rozumiano w znaczeniu orzeczeń sądowych, a w konsekwencji termin ten był pierwotnie używany $\mathrm{w}$ sensie prawniczym (praejudicium in sensu juridico), dodajmy: w sensie pozytywnym i literalnym ${ }^{2}$. Praejudicium in sensu juridico oznacza dosłownie prawny przed-sąd (prae-judicium) w znaczeniu wstępnego osądu (judicium praevium) przed wydaniem właściwego, ostatecznego wyroku, osądu na podstawie przypuszczenia (presumpcji), które w jakimś stopniu antycypuje przyszłe rozwiązanie kwestii prawnej ${ }^{3}$. Tak więc pojęcie przesądu w prawniczym i dosłownym rozumieniu jako wstępnego osądu (sądu tymczasowego), który może zostać skorygowany w dalszym przebiegu procesu prawnego, pozostaje $\mathrm{W}$ związku z pojęciem presumpcji. W czasie oświecenia upowszechniło się filozoficzne znaczenie terminu przesą, a przesąd w znaczeniu filozoficznym (praejudicium in sensu philosophico) jest rozumiany negatywnie a zarazem metaforycznie jako błędny sąd ${ }^{4}$. Słowo Vorurteil w sensie negatywnym traci swe dosłowne znaczenie przed-sądu (Vor-Urteil), czyli sądu tymczasowego, i aspiruje do miana sądu ostatecznego; jako takie, oznacza nieuprawnione podniesienie tego, co tymczasowe, relatywne, do rangi tego, co ostateczne, absolutne. W znaczeniu filozoficznym przesąd uzyskał tym samym w duchu oświeceniowej wykładni negatywne, a zarazem metaforyczne konotacje jako błędny sąd, ulegając dyskredytacji.

\section{KANTA POJĘCIE PRZESĄDU: PRZESĄD JAKO SĄD TYMCZASOWY BLĘDNIE UZNANY ZA SĄD OKREŚLAJĄCY}

Oświeceniowa krytyka przesądów kulminuje w dziele Immanuela Kanta, który w Krytyce władzy sądzenia oświecenie nazywa wolnością

1 Zob. W. Schneiders, Aufklärung und Vorurteilskritik. Studien zur Geschichte der Vorurteilstheorie, Stuttgart-Bad Cannstatt 1983, 38-49.

2 Zob. Tamże.

3 Zob. Tamże, 38-43.

4 Zob. Tamże, 43-49. 
od przesądów ${ }^{5}$. Myśliciel z Królewca przeprowadza analizę przesądów w ramach logiki, przy czym nigdy nie napisał on własnej logiki, opierając się w swych wykładach z logiki na pracy Georga Friedricha Meiera, pt. Auszug aus der Vernunftlehre (1752), a jego wykłady w formie podręcznika zredagował i wydał w 1800 roku Gottlob Benjamin Jäsche ${ }^{6}$. Kant definiuje przesądy w opozycji do sądów tymczasowych oraz sądów określających, ale w definicji przesądu obecne jest zarówno pojęcie sądu tymczasowego, jak i sądu określającego, bo przesąd jest zdefiniowany jako sąd tymczasowy wydany bez zastanowienia i jako taki bezprawnie pretendujący do sądu określającego. Sąd określający to sąd ostateczny, definitywnie prawdziwy, wydawany na podstawie ,zupełnego pojęcia przedmiotu takiego, jakim on jest"7, podczas gdy sąd tymczasowy nie stanowi ostatecznego rozstrzygnięcia i jest sądem o pewnych aspektach danego przedmiotu, dodajmy: przed-sądem, czyli sądem o przedmiocie przed jego dokładnym poznaniem. W języku Kanta sąd tymczasowy jest mniemaniem, a mniemanie to „uznawanie-za-prawdę na podstawie racji poznawczej, która ani subiektywnie, ani obiektywnie nie jest wystarczająca"8. Mniemanie zgodnie z tradycyjną wykładnią Kant odróżnia od wiedzy, którą stanowią sądy określające, przy czym wiedza to „uznawanie-za-prawdę na podstawie racji poznawczej, która zarówno obiektywnie, jak i subiektywnie jest wystarczająca"9.

Zaznaczmy dobitnie, że jeżeli chodzi o samą relację między poznaniem i sądami tymczasowymi, to Kant nie tylko przeciwstawia sądy tymczasowe sądom określającym, lecz także akcentuje związek między nimi, twierdząc, że ,przeważnie wszelkie nasze poznanie zaczyna się od mniemania"10, a „każdy z naszych sądów określających poprzedzany

5 Zob. I. Kant, Krytyka władzy sądzenia, tłum. z niem. J. Gałecki, Warszawa 2004, 211-212.

6 Na temat statusu krytyki przesądów w filozofii Kanta i jej inspiracji zob. W. Schneiders, dz. cyt., 278-292.

7 I. Kant, Encyklopedia filozoficzna wraz z wyborem uwag o metafizyce i listów z lat 1769-1781, tłum. z niem. A. Banaszkiewicz, Kraków 2003, 53.

8 I. Kant, Logika. Podręcznik do wykładów, tłum. z niem. A. Banaszkiewicz, Gdańsk 2005, 88.

9 Tamże, 91.

10 Tamże, 88. 
jest sądem tymczasowym” określających, gdyż do tego potrzeba zupełnego pojęcia przedmiotu takiego, jakim on jest. Jednak nie na podstawie pierwszego rzutu oka wchodzimy w posiadanie takiego pojęcia. Zanim je uzyskamy, musimy najpierw obejrzeć przedmiot z wszystkich stron i odszukać to, co pasuje do wszystkich [jego] zjawisk"12. Nasze poznanie jest poznaniem perspektywicznym, wieloaspektowym, wielostronnym, co oznacza, że natychmiastowy, całościowy wgląd $\mathrm{w}$ dany przedmiot nie jest możliwy, a zupełne poznanie przedmiotu jest efektem jego oglądania z różnych stron i odsłonięcia tego, co jest wspólne wszystkim jego zjawiskom. Kant w tym kontekście podaje przykład poznawania domu: dom najpierw prezentuje się nam z pewnej strony i aby uzyskać zupełne pojęcie domu takim, jakim jest, musimy go obejrzeć z wszystkich stron. W konsekwencji sądy tymczasowe na temat różnych aspektów (wyglądów) przedmiotów mają antycypacyjny charakter i są domniemaniami naprowadzającymi na sądy określające sam przedmiot. Kant nazywa wprost sądy tymczasowe antycypacjami, „gdyż antycypuje się swój sąd o jakiejś rzeczy, zanim uzyska się sąd określający"13. Dlatego sąd tymczasowy jest nie tylko mniemaniem, które może zostać skorygowane lub unieważnione w dalszym przebiegu poznania, lecz także stanowi konieczny punkt wyjścia poznania, toteż w krytycyzmie Kanta dochodzi do rehabilitacji mniemania, ściślej mówiąc, rehabilitacji zawartej w mniemaniu presumpcji. W tym kontekście Werner Schneiders zaznacza, że Kant akcentuje pozytywne, teoriopoznawcze znaczenie presumpcji implikowanej w sądach tymczasowych, objaśniając, że presumpcja oznacza przypuszczenie czy antycypację możliwego poznania na podstawie dotychczasowych danych ${ }^{14}$.

$Z$ tego punktu widzenia presumpcyjny aspekt sądów tymczasowych splata się z ich aspektem heurystycznym i problematycznym ${ }^{15}$. Sądy

11 I. Kant, Encyklopedia filozoficzna, dz. cyt., 53.

12 Tamże.

13 I. Kant, Logika, dz. cyt., 97.

14 Zob. W. Schneiders, dz. cyt., 44, 286-287.

15 Na te trzy aspekty sądów tymczasowych zwraca uwagę W. Schneiders, dz. cyt., 284-287. 
tymczasowe są sądami właściwymi dla pewnego etapu poznania i wymagają potwierdzenia w dalszym przebiegu doświadczenia, a zarazem okazują się konieczne w obrębie heurystyki poznania, ponieważ prowadzą do sądów prawdziwych, stanowią impuls do dalszego badania i mają rozstrzygające znaczenie dla samego procesu odkrywania ${ }^{16}$. „By coś o dk ryć (co ukryte jest albo w nas samych, albo poza nami), potrzeba $\mathrm{w}$ wielu wypadkach szczególnego talentu, trzeba mianowicie wiedzieć, gdzie szukać. Jest to dar prow i zorycznej oceny (judicii praevii), gdzie najprawdopodobniej ukryta jest prawda, tropienia rzeczy i wykorzystania najdrobniejszych przyczyn do dostrzeżenia pokrewieństwa, by wynaleźć lub odkryć to, czego się szuka"17. Aby poznać przedmiot, trzeba uprzednio dysponować maksymą jego badania, to znaczy należy naszkicować tymczasowy plan jego badania na podstawie wstępnego mniemania czy wstępnego oglądu, a maksym badania przedmiotu dostarczają sądy tymczasowe, bez których nasze myślenie pogrążyłoby się w chaosie pojęciowym i nie miałoby w ogóle dostępu do przedmiotu. Kant tym samym bardzo mocno akcentuje wszechobecność sądów tymczasowych w naszym poznaniu w ich w funkcji presumpcyjnego kierowania władzą sądzenia i intelektem: „Sądy tymczasowe są bardzo potrzebne, ba, nie można się bez nich obejść, używając intelektu we wszelkiego rodzaju rozmyślaniach i badaniach. Albowiem ich zadaniem jest kierowanie intelektem w jego poszukiwaniach oraz dostarczanie mu rozmaitych środków do tego służących"18. Mając na uwadze heurystyczną funkcję sądów tymczasowych, myśliciel z Królewca postuluje opracowanie logiki sądów tymczasowych: „Sądy te są domniemaniami naprowadzającymi na sądy określone i można by napisać logikę sądów tymczasowych, wskazującą na przykład, gdzie można, a gdzie nie można im ufać; gdyż wiele z nich jest tego rodzaju, że można zdać się na nie z dużą pewnością - wyłaniają się one z praw intelektu"19.

16 Zob. R. Godel, Vorurteil-Anthropologie-Literatur. Der Vorurteilsdiskurs als Modus der Selbstaufklärung im 18. Jahrhundert, Tübingen 2007, 16.

17 I. Kant, Antropologia w ujęciu pragmatycznym, tłum. z niem. E. Drzazgowska, P. Sosnowska, Warszawa 2005, 150. Zob. R. Godel, dz. cyt., 16.

18 I. Kant, Logika, dz. cyt., 97.

19 I. Kant, Encyklopedia filozoficzna, dz. cyt., 54. 
Ta logika sądów tymczasowych stanowiłaby rodzaj heurystyki poznania i sprowadzałaby się do logiki sądów problematycznych jako antycypacji możliwego poznania, jako że sądy tymczasowe są sądami problematycznymi. W Krytyce czystego rozumu sądy problematyczne są określone jako „takie sądy, w których stwierdzenie lub przeczenie przyjmuje się jedynie za możliwe (dowolne)" i jako takie są odróżnione od sądów asertorycznych, zawierających uznanie stwierdzenia bądź przeczenia za prawdziwe oraz od sądów apodyktycznych, uznających je za konieczne ${ }^{20}$. „Dlatego to - pisze Kant - takie sądy mogą oczywiście być też fałszywe, a jednak wzięte problematycznie mogą być warunkami poznania prawdy"21. Zaznaczmy w tym miejscu, że Kant rozpatruje prawdziwość poznania zarówno od strony formalnej, jak i materialnej. Od strony formalnej prawdziwość poznania oznacza jego „zgodność (...) z ogólnymi i formalnymi prawami intelektu i rozumu”22. Poznanie zaś jest prawdziwe co do treści, jeżeli zgadza się ze swym przedmiotem, przy czym tej przedmiotowej zgodności nie można wydedukować ze świadomości, tak że poznanie, pomimo że spełnia formalne warunki prawdziwości, może przeczyć przedmiotowi. W związku z tą problematyką Dieter Lohmar ${ }^{23}$ zauważa, że Kant dopuszcza „, fałszywe poznanie”, zaznaczając, że „fałszywe poznanie” również odnosi się do przedmiotów i wskazując fragment Krytyki czystego rozumu, w którym myśliciel z Królewca mówi o prawdziwości jako „zgodności poznania z jego przedmiotem” i przyznaje zarazem, iż ,poznanie (...) jest fałszywe, jeżeli nie zgadza się z przedmiotem, do którego się je odnosi, jakkolwiek zawiera w sobie coś, co zapewne mogłoby być ważne dla innych przedmiotów" ${ }^{24}$. Skoro poznanie jest fałszywe nie w tym sensie, że uchybia formalnym warunkom prawdziwości, lecz w tym znaczeniu, że nie zgadza się ze swym przedmiotem, chociaż „zawiera w sobie coś, co zapewne mogłoby być ważne dla innych przedmiotów", poznanie

20 I. Kant, Krytyka czystego rozumu, tłum. z niem. R. Ingarden, Kęty 2001, A $74-75 /$ B 100.

21 Tamże, A 75/B 100.

22 Tamże, A 59/B 84.

23 Zob. D. Lohmar, Erfahrung und kategoriales Denken. Hume, Kant und Husserl über vorprädikative Erfahrung und prädikative Erkenntnis, Dordrecht 1998, 105.

24 I. Kant, Krytyka czystego rozumu, dz. cyt., A 58/B 83. 
to - odwołajmy się do komentarza Lohmara - okazuje się ,zdolne do prawdy" "25. Dlatego Kant pisze, że ,wszystkie nasze sądy muszą zawierać w sobie coś z prawdy”, to znaczy „błąd totalny jest niemożliwy”26. Z tej przyczyny nawet fałszywy sąd, przyjmowany tymczasowo, na próbę, pełni funkcję heurystyczną, ponieważ ,służy przecież (jak wskazanie błędnej drogi wśród tych, które można obrać) do znalezienia sądu prawdziwego"27.

Sądy tymczasowe jako mniemania nie stanowią zatem jeszcze poznania, ponieważ poznanie jest domeną sądów określających, a zarazem są wyraźnie odgraniczone od pseudopoznania (przesądów). Ściślej mówiąc, sądy tymczasowe mogę nie tylko prowadzić do sądów określających, lecz także ulegać degradacji do przesądów. Przesądy bowiem to sądy tymczasowe, które zostają uznane za sądy określające, definitywnie prawdziwe, a takie uznanie jest całkowicie bezzasadne i generuje iluzję, bo sądy tymczasowe są jedynie presumpcjami, antycypacjami naprowadzającymi na prawdziwe poznanie. ,Jeśli to, co jest presumpcją, uważa się za sąd określający, to powstaje z tego iluzja, błąd"28. Można powiedzieć, że przesąd to sąd tymczasowy, który jest pozbawiony swej funkcji heurystycznej i nie stanowi impulsu do dalszych badań, ponieważ zostaje uznany za sąd definitywny, chociaż jest charakterystyczny dla pewnego etapu w procesie poznania, a w konsekwencji przesąd to sąd tymczasowy wydawany bezwiednie, pośpiesznie, bez zastanowienia. O ile sądy tymczasowe, mylnie uznane za sądy określające, stanowią założenia dalszych sądów, o tyle należy je potraktować jako fałszywe zasady, z których wypływają błędne sądy, dlatego przesądy są również sądami, z których pochodzą inne sądy. Dodajmy, że Kant za Meierem skłaniał się ku poglądowi, iż przesądy różnią się od sądów tymczasowych pod względem formy, jako że treściowo sąd w przesądzie i sądzie tymczasowym pozostaje zasadniczo identyczny, tak że przesądy są bezwzględnie fałszywe co do formy, a co do treści mogą

25 D. Lohmar, dz. cyt., 105

26 I. Kant, Encyklopedia filozoficzna, dz. cyt., 52.

27 I. Kant, Krytyka czystego rozumu, dz. cyt., A 75/B 101.

28 I. Kant, Encyklopedia filozoficzna, dz. cyt., 51. 
być prawdziwymi sądami ${ }^{29}$. Dlatego w Logice czytamy: „Niekiedy przesądy są prawdziwymi sądami tymczasowymi, niewłaściwe jest tylko uznawanie ich za zasady lub sądy o k re śl a ją c e" 30 .

Źródłem wszelkich sądów jest rozum, jako że sądy są efektem jego różnych możliwych zastosowań, a rozum jako zdolność tworzenia sądów podlega krytyce, która zabrania wydawania przesądów: sama krytyka (gr. krinein: rozróżniać, osądzać, rozstrzygać, oddzielać) jest rozróżnianiem możliwości użycia rozumu, osądzaniem ich i oddzielaniem użycia właściwego od nieuprawnionego. Zdaniem Kanta, postępowanie krytyczne wymaga zastanowienia; samo zaś zastanowienie (reflexio) w swej funkcji transcendentalnej jest ,świadomością stosunku danych [nam] przedstawień do różnych naszych źródeł poznania" ${ }^{31}$ (zmysłowości czy intelektu), z których te przedstawienia wypływają, i to właśnie zastanowienie transcendentalne chroni przed pomieszaniem odmiennych rodzajów użycia władz poznawczych. Brak owego zastanowienia generuje przesądy, gdyż przesądy to sądy wydawane bez zastanowienia; w konsekwencji przesądy to nie tylko sądy o przedmiocie, zanim przedmiot zostanie wyraźnie poznany, lecz także sądy bezrefleksyjnie uznane za prawdziwe, przed rozpoznaniem ich źródła i granic. Innymi słowy, przesąd powstaje wtedy, gdy mniemanie uznajemy za coś więcej niż mniemanie, gdy mniemamy bez zastanowienia, bez świadomości mniemania, bezprawnie podnosząc je do rangi wiedzy. „Jeśli (...) przyjmujemy sądy bez (...) zastanowienia, które konieczne jest również tam, gdzie nie przeprowadza się żadnego badania, to powstają z tego przesądy, czyli pryncypia wydawania sądów na podstawie przyczyn podmiotowych, które mylnie brane są za racje przedmiotowe" ${ }^{32}$.

Tak więc brak odróżnienia sądów tymczasowych od sądów określających prowadzi do przesądów, charakterystycznych dla filozofii niekrytycznej, która sprowadza się do wydawania sądów bez rozróżniania władz poznawczych, z jakich one wypływają. Kant rozpoznaje wprawdzie pozaracjonalne źródła przesądów, jak pośpiech, skłonność,

29 Zob. W. Schneiders, dz. cyt., 289-291.

30 I. Kant, Logika, dz. cyt., 98.

31 I. Kant, Krytyka czystego rozumu, dz. cyt., A 260/B 316.

32 I. Kant, Logika, dz. cyt., 98. 
przyzwyczajenie, naśladownictwo, ale zarazem przyznaje, że to sam rozum ulega przesądom, pozostając $\mathrm{w}$ stanie biernym, a rozum $\mathrm{w}$ stanie biernym to rozum leniwy, pozbawiony spontaniczności. Przesądy są rozumiane jako efekt biernego użycia rozumu. „Skłonność do bierności - objaśnia Kant - a zatem do heteronomii rozumu, nazywa się przesądem; a największym spośród wszystkich przesądów jest przedstawianie sobie przyrody jako niepodlegającej prawidłom, jakie u jej podstawy kładzie intelekt przez jej własne istotne prawo: tzn. zabobon"33. Przesądom może zaradzić tylko oświecenie. Oświecenie to „maksyma sposobu myślenia wolnego od przesądów”, która polega na tym, aby myśleć samodzielnie (Selbstdenken), to znaczy „maksyma nigdy nie biernego rozumu” ${ }^{34}$. „Uwolnienie od zabobonu nazywa się oświeceniem, gdyż jakkolwiek nazwa ta przysługuje także uwolnieniu od przesądów w ogóle, to zabobon zasługuje jednak w pierwszym rzędzie (in sensu eminenti) na miano przesądu; ślepota bowiem, jaką sprowadza zabobon i, co więcej, nawet obowiązkowo jej wymaga, najwyraźniej świadczy o potrzebie podlegania kierownictwu ze strony innych a tym samym o stanie rozumu biernego"35. Kantowska krytyka przesądów jest ukierunkowana zarówno na ich zwalczanie, jak i unikanie; co więcej, unikanie przesądów - zdaniem Wernera Schneidersa - ma pierwszeństwo przed ich zwalczeniem, ponieważ krytyka przesądów ma charakter wyprzedzający (antycypujący): jest nie tyle zorientowana destrukcyjnie i retrospektywnie na kwestionowanie pewności poznania, ile konstruktywnie i prospektywnie na zapewnienie możliwej pewności poznania ${ }^{36}$. Dlatego istotnym elementem krytyki przesądów jest zawieszenie sądu (Urteilsenthaltung), które ma charakter prewencyjny i ,polega (...) na postanowieniu, iż nie dopuści się do tego, by sąd wyłącznie t y m c z a s o w y stał się sądem o k r e ś 1 a j ą c y m"37. Ściślej mówiąc, zawieszeniu podlegają uzurpujące roszczenia sądu tymczasowego do uznawania go za sąd określający, dodajmy: uzurpujące roszczenia absolutyzujące

\footnotetext{
33 I. Kant, Krytyka władzy sądzenia, dz. cyt., 211.

34 Tamże, 210-211.

35 Tamże, 211-212.

36 Zob. W. Schneiders, dz. cyt., s. 305.

37 I. Kant, Logika, dz. cyt., 95-96.
} 
to, co partykularne, niepewne, tymczasowe, a w konsekwencji celem owego zawieszenia jest niedopuszczenie do fałszywej absolutyzacji jakiejś określonej perspektywy badania rzeczy. Kant pisze: „Wszyscy ludzie żywią przesądy, tyle że odmiennego rodzaju. Ten tylko jest od nich wolny, komu łatwo przychodzi rozważenie rzeczy z jakiegoś całkiem innego punktu widzenia" 38 . Komentując ten fragment Encyklopedii filozoficznej Kanta, Werner Schneiders zaznacza, że Kant akcentując perspektywiczność poznania, rozumie przesąd jako „dogmatyzację określonej perspektywy”, dlatego „uwolnienie od przesądów polega na przezwyciężeniu determinacji przez jakiś określony punkt widzenia”, „a zmiana perspektywy powoduje (w miarę możliwości) zbliżanie się do absolutnego stanowiska a przez to do obiektywności"39.

Zawieszenie sądu typowe dla krytyki przesądów ma istotne znaczenie dla Kantowskiej metody krytycznej, ponieważ Kant rozróżnia trzy stadia filozofii: dogmatyzm, sceptycyzm i krytycyzm, a zarówno dogmatyzm jako nieograniczone zaufanie do naszych władz poznawczych bez ich uprzedniej krytyki, jak i sceptycyzm jako brak zaufania do tych władz również bez takiej krytyki - okazują się przesądami ${ }^{40}$. Sam krytycyzm kieruje się maksymą zawieszenia sądów generowanych przez dogmatyzm i sceptycyzm, to znaczy sądów przyjmowanych bez zastanowienia, uznawanych za ostateczne bez zbadania ich źródła i granic. Metoda krytyczna stanowi w jakimś sensie poszukiwanie drogi pośredniej między dogmatyzmem i sceptycyzmem; jako taka, okazuje się przy tym bliższa sceptycyzmowi niż dogmatyzmowi, ponieważ charakterystyczna dla tej metody maksyma zawieszania sądów jest zapożyczona ze sceptycyzmu. W krytycyzmie dochodzi jednak do chwilowego zawieszenia sądu, a nie jak w sceptycyzmie - do zawieszenia stałego (ostatecznego): sąd zawieszamy, o ile nie istnieją jeszcze wystarczające podstawy do uznania jego prawdziwości, a samo zawieszenie sądu ma

38 I. Kant, Encyklopedia filozoficzna, dz. cyt., 55.

39 W. Schneiders, dz. cyt., 294 (przypis 19).

40 Zob. I. Kant, O odkryciu, po którym wszelka nowa krytyka czystego rozumu jest zbędna ze względu na istnienie wcześniejszej, tłum. z niem. Translatorium Filozofii Niemieckiej Instytutu Filozofii UMK pod kierunkiem Mirosława Żelaznego, w: Tenże, Dzieła zebrane, t. 6: Pisma po roku 1781, red. M. Jankowski, T. Kupś, M. Marciniak, M. Żelazny, Toruń 2012, 224-225. 
na celu zbadanie jego źródła i odnalezienie racji, na której się opiera: „Zawieszenie sądu może mieć dwojaki cel: a l b o aby odszukać racje dla sądu określającego, albo aby $n$ i g d y nie wydawać sądów. W pierwszym wypadku wstrzymanie się od sądu ma charakter k r y t y c z n y (suspensio iudicii indagatoria), w drugim - s c e p t y c z n y (suspensio iudicii sceptica). Sceptyk bowiem rezygnuje z wszelkiego wydawania sądów, natomiast prawdziwy filozof jedynie zawiesza swój sąd, o ile nie ma jeszcze wystarczających podstaw do uznania czegoś za prawdę"41.

\section{HUSSERLA POJĘCIE PRZESĄDU: PRZESĄD JAKO NIEJASNOŚĆ ZROZUMIALA SAMA PRZEZ SIE}

Edmund Husserl w Kryzysie nauk europejskich przesądy określa następująco: „Bycie samodzielnym myślicielem (Selbstdenker), autonomicznym filozofem wypełnionym wolą uwolnienia się od wszystkich przesądów (Vorurteile) wymaga od niego zrozumienia, że wszystko, co u niego zrozumiałe samo przez się to przesądy, że wszystkie przesądy są zsedymentowanymi niejasnościami pochodzącymi z tradycji (a nie jedynie sądy niepewne co do swej prawdy) i że dotyczy to także tego wielkiego zadania, tej idei, która zwie się »filozofią «"42. Przesąd Husserl określa zatem jako niejasność zrozumiałą samą przez się, to znaczy narzucającą się przed wszelkim poznaniem, nieuświadomioną, spełnianą bezwiednie, niepoddaną refleksji. Dlaczego jednak przesądy są zsedymentowanymi niejasnościami pochodzącymi z tradycji? W znaczeniu fenomenologicznym niejasność oznacza brak oczywistości, a sama oczywistość stanowi źródłowo prezentującą naoczność jako podstawę prawomocności wszelkich teorii, wszelkich twierdzeń, wszelkich pojęć. W poznaniu nigdy jednak nie osiągamy czystej prezentacji wolnej od tego, co wpółdomniemywane, od tego, co w charakterze presumpcji

41 I. Kant, Logika, dz. cyt., 96.

42 E. Husserl, Die Krisis der europäischen Wissenschaften und die transzendentale Phänomenologie. Eine Einleitung in die phänomenologische Philosophie, hrsg. von W. Biemel, w: Husserliana, Gesammelte Werke, Bd. 6, Den Haag 1962, 73. Cyt. za polskim przekładem fragmentów Kryzysu nauk europejskich - E. Husserl, Kryzys nauk europejskich i fenomenologia transcendentalna, tłum. z niem. S. Walczewska, Torun 1999, 78. 
antycypowane, a to, co jedynie współdomniemywane, zawsze już z góry obowiązuje przed wszelką możliwą eksplikacją, przed wszelkim możliwym wyrażeniem czy uchwytującym zwróceniem uwagi. Co więcej, dlatego, że antycypuję to, co niespostrzeżone, mogę to, co spostrzeżone, ująć jako pewien przedmiot. Gdyby moje poznanie było czystą percepcją bez antycypacji, nie widziałbym żadnych przedmiotów ${ }^{43}$. Nasze doświadczenie jest zatem co do istoty nieokreślone, stanowiąc splot tego, co widziane, naocznie dane, i tego, co jedynie domniemywane, presumpcyjnie antycypowane, i w tym należy upatrywać źródła przesądów ${ }^{44}$.

Stąd wniosek, że zawsze już ,wiemy” więcej niż widzimy. To „więcej”, ta nadwyżka specyficznej, presumpcyjnej „wiedzy” w stosunku do widzenia pochodzi z tradycji, która generuje przesądy. Nie chodzi tu jednak o tradycję w wąskim sensie, która pochodzi z przekazu i obowiązuje w charakterze dziedzictwa jako ogół przyjętych przekonań, które określają nasz sposób bycia, lecz tradycję w sensie szerszym zawartą w każdym prostym akcie doświadczenia, tradycję w znaczeniu usedymentowanej historii intencjonalnego życia oddziałującej genetycznie w dwojaki sposób: „p o pie r w s ze, w formie możliwych reprodukcji przypomnieniowych podczas przechodzenia przez pierwotno-genetyczne retencje, które przyłączają się całkowicie bezpośrednie; p o d rugi e, [jako] oddziaływanie »apercepcyjne«, dzięki któremu w nowej, [ale] podobnej sytuacji coś, co występuje jako

43 Zob. E. Husserl, Zur phänomenologischen Reduktion. Texte aus dem Nachlass (1926-1935), hrsg. von S. Luft, w: Husserliana, Gesammelte Werke, Bd. 34, DordrechtBoston-London 2002, 441-445. Zob. również A. Aguirre, Genetische Phänomenologie und Reduktion. Zur Letztbegründung der Wissenschaft aus der radikalen Skepsis im Denken E. Husserls, Den Haag 1970, 174-181.

44 W fenomenologii presumpcja nie odnosi się pierwotnie do sądów, lecz do samego przebiegu doświadczenia. Jako taka, oznacza tkwiącą w każdym spostrzeżeniu antycypację (w sensie wstępnego mniemania), która domniemuje na podstawie dotychczasowego przebiegu doświadczenia przyszłe związki spostrzeżeniowe zgodne z tym przebiegiem. Takie presumpcyjne antycypowanie pozostawia w zawieszeniu dalszy ciąg doświadczenia, dopuszczając możliwość zmiany tego ciągu lub jego unieważnienia. Dlatego presumpcja w sensie antycypacji wymaga potwierdzenia w dalszym przebiegu doświadczenia, a „presumpcyjny” oznacza przeciwieństwo ,apodyktycznie pewnego". 
już tak czy inaczej ukonstytuowane, jest apercypowane w podobny sposób"45. W tym kontekście Husserl powie w Doświadczeniu i sądzie, że nasze doświadczenie implikuje pewną współwiedzę (Mitwissen) czy przedwiedzę (Vorwissen), wiedzę nietematyczną, presumpcyjną, która wymaga potwierdzania $\mathrm{w}$ dalszym przebiegu doświadczenia i otwiera tym samym możliwość stawania się poznania (jego historyczności); wiedzę o doświadczanej rzeczy w aspekcie tych jej własności, które się jeszcze nie ukazały, wiedzę, która „choć treściowo nieokreślona lub nie w pełni określona, nie jest zupełnie pusta"; a bez tej przedwiedzy żadne doświadczenie rzeczy nie byłoby możliwe, tak że ,nie ma doświadczenia w prostym sensie początkowego doświadczenia jakiejś rzeczy, które ujmując tę rzecz po raz pierwszy, nie »wie« o niej nic ponad to, czego się wtedy dowiaduje"46.

Według Husserla tym, co z góry obowiązuje w charakterze uniwersalnej presumpcji jako stała, sama przez się zrozumiała podstawa, jest świat, gdyż ,realny świat istnieje tylko w [horyzoncie] stale wyznaczanej wstępnie presumpcji, że doświadczenie stale będzie przebiegać w jednakowym stylu konstytutywnym"47. W Kryzysie czytamy: „Świat jest jedynym uniwersum danego wstępnie tego, co samo przez się zrozumiałe"48. Husserl pisze wprost: „,...) świat jest dla mnie stale-żywym przesądem i w pewnym sensie uniwersum wszystkich moich przesądów w naturalnym życiu" ${ }^{49}$. Naturalny świat jest tym, czego doświadczamy i o czym mamy nietematyczną, presumpcyjną wiedzę, która nie pochodzi z refleksji, lecz jest przyjmowana jako zrozumiała

45 E. Husserl, Logika formalna i logika transcendentalna. Próba krytyki rozumu logicznego, tłum. z niem. G. Sowinski, Warszawa 2011, 306. Na temat tradycji w węższym i szerszym sensie zob. E. Husserl, Zur phänomenologischen Reduktion, dz. cyt., 442-445.

46 E. Husserl, Doświadczenie i sąd. Badania nad genealogia logiki, tłum. z niem. B. Baran, Warszawa 2013, 41.

47 E. Husserl, Logika formalna i logika transcendentalna, dz. cyt., 245.

48 E. Husserl, Die Krisis der europäischen Wissenschaften und die transzendentale Phänomenologie, dz. cyt., s. 183. Cyt. za polskim przekładem fragmentów Kryzysu nauk europejskich - E. Husserl, Wybór pism, tłum. z niem. S. Walczewska, w: K. Święcicka, Husserl, Warszawa 1993, 188.

49 E. Husserl, Späte Texte über Zeitkonstitution (1929-1934). Die C-Manuskripte, hrsg. von D. Lohmar, w: Husserliana, Materialien, Bd. 8, Dordrecht 2006, 41. 
sama przez się. Nieprzypadkowo Husserl mówi o nietematycznej, anonimowej, to znaczy niepoddanej refleksji pewności świata. „Świadomość świata-czytamy w Doświadczeniu i sadzie-jest świadomościa w modus pewności wiary (Glaubensgewißheit)" ${ }^{50}$. Ta przeświadczeniowa pewność określa sens generalnej tezy nastawienia naturalnego ${ }^{51}$. Sam termin ,generalna teza nastawienia naturalnego” jest niefortunnym wyrażeniem, bo wywołuje konotacje związane z sądem, podczas gdy, według Husserla, teza generalna nie jest sądem, lecz poprzedzającym wszelkie sądy i w nich założonym niewyrażonym uznaniem istnienia. „Teza generalna - odwołajmy się do Idei I - mocą której realny świat otaczający jest nie tylko w ogóle ujęciowo uświadamiany, lecz uświadamiany jako istniejąca »rzeczywistość«, polega naturalnie nie n a ja ki mś o s obny m a kci e, na jakimś artykułowanym sądzie o istnieniu. Jest ona wszak czymś trwale utrzymującym się przez cały okres trwania tego nastawienia, tj. podczas naturalnego przytomnego życia. To, co za każdym razem spostrzegane, jasno lub niejasno uobecnione, krótko: wszystko z naturalnego świata, co jest uświadamiane doświadczeniowo i przed wszelkim myśleniem, posiada w swej całości i we wszystkich wyodrębnionych członach charakter [czegoś] »tu [istniejącego]《 (»da«), czegoś »obecnego [pod ręką]« (»vorhanden«); charakter, na którym z istoty da się oprzeć wyraźny (orzekający) sąd egzystencjalny z nim zgodny. Jeżeli wypowiadamy ten sąd, to przecież wiemy, żeśmy w nim jedynie uczynili tematem i ujęli orzekająco to, co nietematycznie, nie pomyślane, nie orzeczone już tkwiło jakoś w pierwotnym doświadczeniu, resp. w tym, co doświadczane, tkwiło jako charakter czegoś »istniejącego« (des »Vorhanden«)"52.

50 E. Husserl, Doświadczenie i sąd, dz. cyt., 40.

51 Zob. E. Husserl, Idee czystej fenomenologii i fenomenologicznejfilozofii. Księga pierwsza, tłum. z niem. D. Gierulanka, Warszawa 1975, 86-88.

52 Tamże, 88. Ściślej mówiąc, teza nastawienia naturalnego jest praprzeświadczeniem (Urglaube) czy pramniemaniem (Urdoxa), prapostacią wszelkiego uznawania istnienia, przenikającą wszelkie modi żywienia przeświadczenia i związane z nimi sądy, potraktowaną jako podstawa wszelkiego poznania i działania. Zob. Tamże, 336-342. Jako taka, oznacza ,bierna wiarę bytowa, która nie ma jeszcze w sobie nic z dokonania poznawczego", i należy do obszaru pierwotnej pasywności, poprzedzającej wszelką podmiotową aktywność, a więc również aktywność wydawania sądów. Zob. 
Samą tezę generalną należy zatem rozumieć nie jako sąd o istnieniu (Urteil), lecz - jak przyznaje sam Husserl - jako uniwersalny przesąd (Vorurteil) $^{53}$. Ściślej mówiąc, teza generalna stanowi przesąd rozumiany dosłownie jako przed-sąd (Vor-Urteil), to znaczy niewyrażone przeświadczenie o istnieniu świata poprzedzające każde konkretne, artykułowane w sądzie uznanie istnienia i w sposób skryty założone w całym naturalnym doświadczeniu. Jako przed-sąd założony we wszelkim doświadczeniu, ma ona charakter przeświadczenia (Glaube), które można rozumieć w znaczeniu greckiej doksa, czyli ,,przedteoretycznej, niepredykatywnej »wiedzy«, (...) niesprawdzonego mniemania" 54 , dodajmy: mniemania o charakterze uniwersalnej apercepcji, przenikającej całe naturalne doświadczenie. Ta uniwersalna apercepcja jest rozumiana jako „,apercepcja antycypująca” i zarazem prawomocna, bo stale się potwierdzająca w przebiegu doświadczenia, i tę stałą, uniwersalną, antycypującą apercepcję Husserl w Phänomenologische Psychologie nazywa wprost przesądem ${ }^{55}$.

Presumpcyjny charakter tezy nastawienia naturalnego polega na tym, że jest ona zawieszona między faktycznością i oczekiwaniem: to, że świat istnieje, stanowi fakt uznany w tezie, a uznanie to dokonuje się na mocy oczekiwania, że przyszły faktyczny ciąg doświadczeń będzie stale potwierdzał jego dotychczasowy jednozgodny przebieg, jako że nie można wykluczyć możliwości załamania się stylu jednozgodności; co więcej, nie sposób wykluczyć możliwości rozpłynięcia się doświadczenia w niedających się wyrównać niezgodnościach, to znaczy możliwości

E. Husserl, Doświadczenie i sad, dz. cyt., 66-68. Z tego punktu widzenia przedrostek przed-(vor-) w przed-sadzie (Vor-Urteil), jakim jest teza generalna, oznacza ,poprzedzający wszelkie sądy i w nich z góry założony".

53 Zob. E. Husserl, Phänomenologische Psychologie. Vorlesungen Sommersemester 1925, hrsg. von W. Biemel, w: Husserliana, Gesammelte Werke, Bd. 9, Den Haag 1968, 528-531; S. Taguchi, Das Problem des ,Ur-Ich” bei Edmund Husserl. Die Frage nach der selbstverständlichen „Nähe” des Selbst, Dordrecht 2006, 16.

${ }^{54}$ S. Luft, „Phänomenologie der Phänomenologie”. Systematik und Methodologie der Phänomenologie in der Auseinandersetzung zwischen Husserl und Fink, Dordrecht-Boston-London 2002, 74.

55 Zob. E. Husserl, Phänomenologische Psychologie, dz. cyt., 528-531. 
unicestwienia świata ${ }^{56}$. Gdy jednak presumpcję podnosi się do rangi tego, co apodyktycznie pewne, dochodzi do niedorzecznego, naturalistycznego zabsolutyzowania świata, skutkującego całkowitym zapomnieniem subiektywności nadającej mu sens, zapomnieniem, które doprowadziło do choroby ludzkiego ducha, jaką jest kryzys europejskiego człowieczeństwa. Na temat naturalistycznej interpretacji świata Husserl pisze: „Ta interpretacja pochodzi z fi 1 o z of i c z n e g o zabsolutyzowania świata, które jest całkowicie obce naturalnemu jego traktowaniu. To traktowanie jest właśnie naturalne, żyje naiwnie w spełnianiu opisanej przez nas generalnej tezy, nie może zatem nigdy stać się niedorzeczne. Niedorzeczność rodzi się dopiero wtedy, gdy się filozofuje i szukając ostatecznej wiedzy o sensie świata, nie zauważa się wcale, że świat sam cały swój byt posiada jako »sens«, który zakłada absolutną świadomość jako pole [operacji] nadawania sensu"57. Implikowana w naturalizmie absolutyzacja świata jest rezultatem uzurpujących roszczeń nauk pozytywnych, które ulegają zaślepieniu ideą świata jako bytu w sobie, wolnego od wszelkiej relatywności i subiektywności, przy czym ideę „w sobie" pozostającą w korelacji z ideą poznania obiektywnego, obowiązującego „dla każdego” i „,raz na zawsze”, można potraktować jako naiwność teoretyczną ${ }^{58}$. W ten sposób nauki pozytywne „kierujące się ideą definitywności" 59 nie tylko podzielają tezę nastawienia naturalnego, lecz również ją dogmatyzują, zacierając bezwiednie (bez zastanowienia) różnicę między presumpcyjnym charakterem tezy a definitywnym charakterem poznania obiektywnego, a zatarcie tej różnicy skutkuje pomieszaniem przed-sądów z sądami ostatecznymi, pomieszaniem, którego rezultatem są przesądy w negatywnym znaczeniu, przesądy naturalistyczne, to znaczy naiwności wyższego rzędu, teoretyczne, przenikające nauki pozytywne. W tym kontekście Sebastian Luft mówi

56 Zob. E. Husserl, Idee czystej fenomenologii i fenomenologicznej filozofii, dz. cyt., 146-147. Zob. również T. Seebohm, Die Bedingungen der Möglichkeit der Transzendental-Philosophie. Edmund Husserls transzendental-phänomenologischer Ansatz, dargestellt im Anschluss an seine Kant-Kritik, Bonn 1962, 59-60.

57 E. Husserl, Idee czystej fenomenologii i fenomenologicznej filozofii, dz. cyt., 171.

58 Zob. E. Husserl, Doświadczenie i sąd, dz. cyt., 51-53.

59 Tamże, 52. 
o przesądzie w „dobrym” i ,złym” sensie ${ }^{60}$. Generalna teza nastawienia naturalnego stanowi przesąd w pozytywnym sensie, a dokładnie: przed-sąd, właściwy naiwności nastawienia naturalnego, naturalnego, czyli przednaukowego, podczas gdy przesąd w negatywnym sensie (przesąd naturalistyczny) stanowi teoretyczne, typowe dla nauk pozytywnych zdogmatyzowanie naiwności zawartej w tezie nastawienia naturalnego ${ }^{61}$. Owo zdogmatyzowanie skutkuje zapoznaniem presumpcyjnego charakteru tezy i podniesieniem tego, co tymczasowe, relatywne, do rangi tego, co ostateczne, absolutne, a w efekcie owej dogmatyzacji samo nastawienie naturalne ulega naturalistycznemu zafałszowaniu.

Celem fenomenologii jest - jak już zaznaczyliśmy - uwolnienie poznającej świadomości od przesądów. Nastawienie fenomenologiczne, w odróżnieniu od nastawienia naturalnego, jest nastawieniem krytyczno-refleksyjnym: nie przyjmuje żadnych niejasnych, samozrozumiałych założeń (przesądów), a zarazem znamionuje zwrot „od obiektywistycznego doświadczenia świata do subiektywnych warunków możliwości poznania"62. W tym kontekście Shigeru Taguchi zauważa, że problematyzację tego, co naturalnie zrozumiałe samo przez się oraz uczynienie go transcendentalnie zrozumiałym, można uznać za charakterystyczną metodę fenomenologii ${ }^{63}$. Nieprzypadkowo w Kryzysie nauk europejskich czytamy: „Na początku fenomenolog żyje takim paradoksem, że to, co samo przez się zrozumiałe, musi widzieć jako problematyczne, jako zagadkowe oraz że odtąd nie może mieć żadnego innego problemu naukowego poza tym, by uniwersalną samą przez się zrozumiałość istnienia świata - która dla niego jest największą ze wszystkich zagadek przemienić w zrozumiałość [rzeczywistą]"'64. Jeżeli zatem zastanowimy się nad tym, jak należy rozumieć tezę, że świat jest, to samo istnienie

60 Zob. S. Luft, dz. cyt., 61-66.

${ }_{61}$ Zob. Tamże, 61-66, 72-78.

62 G.H. Shin, Die Struktur des inneren Zeitbewußtseins. Eine Studie über den Begriff der Protention in den veröffentlichten Schriften Edmund Husserls, Bern 1978, 73.

63 Zob. S. Taguchi, dz. cyt., 3-22.

${ }^{64}$ E. Husserl, Die Krisis der europäischen Wissenschaften und die transzendentale Phänomenologie, dz. cyt., 183-184. Cyt. za polskim przekładem fragmentów Kryzysu nauk europejskich - E. Husserl, Wybór pism, dz. cyt., 188. 
świata staje się zagadką ${ }^{65}$. To zastanowienie umożliwia opuszczenie obszaru nastawiania naturalnego. W nastawieniu naturalnym bowiem nie daje się tematyzować świadomość obowiązywania świata tego nastawienia, ponieważ nastawienie naturalne pozostaje dla samego siebie zakryte, a w efekcie opuszczamy nastawienie naturalne wtedy, gdy czynimy je przedmiotem badań fenomenologicznych, problematyzujemy ważność naszego naiwnego uznawania świata i odsłaniamy u k r y t y, prawdziwy sens owego uznawania ${ }^{66}$.

Krytyczna problematyzacja tego, co zrozumiałe samo przez się, implikuje zawieszenie jego obowiązywania, bo przesąd można tematyzować wtedy, gdy zdystansujemy się wobec niego, wyłączymy jego obowiązywanie. „Na początku krytyki poznania - pisze Husserl - należy tedy opatrzyć wskaźnikiem problematyczności cały świat, fizyczną i psychiczną przyrodę, w końcu także [nasze] własne ludzkie Ja, wraz ze wszystkimi naukami, które odnoszą się do tych przedmiotów. Ich byt, ich moc obowiązująca pozostają w zawieszeniu" ${ }^{67}$. Od krytyki poznania nieodzowna jest zatem epoché, zawieszenie tego, co w naszym nastawieniu naturalnym uchodzi za bezproblematyczne, samozrozumiałe. Ściślej mówiąc, zadaniem krytyki poznania jest zawieszenie przesądów, w szczególności zawieszenie przesądu wszelkich przesądów, jakim jest generalna teza nastawienia naturalnego, dodajmy: zawieszenie chwilowe, umożliwiające badanie naszych przesądów pod kątem prawomocności i odróżnienie przesądów prawdziwych od fałszywych. Innymi słowy, przesądy zawieszamy po to, aby zbadać podstawę ich prawomocności, a w wyniku wykazania braku takiej prawomocności demaskujemy przesądy jako bezzasadne, uzurpujące roszczenia, fałszywie absolutyzujące relatywne prawdy, przesłaniające prawdziwy obraz świata. Stosownie do rozróżnienia przesądów w znaczeniu pozytywnym i negatywnym sama krytyka poznania ma zatem sens zarówno pozytywny, jak i negatywny.

65 Zob. S. Taguchi, dz. cyt., 14-17.

66 Zob. E. Husserl, Die Krisis der europäischen Wissenschaften und die transzendentale Phänomenologie, dz. cyt., 151. Zob. również S. Luft, dz. cyt., 61-66.

67 E. Husserl, Idea fenomenologii. Pięć wykładów, tłum. z niem. J. Sidorek, Warszawa 1990, 38 . 
Dlatego Husserl mówi o epoché w odniesieniu do wszelkich przesądów, a ogół przesądów stanowi tradycję ${ }^{68}$. Zawieszenie przesądów oznacza w istocie powstrzymanie się od ich bezrefleksyjnego spełniania, to znaczy poddanie ich refleksji (rozpoznanie) ${ }^{69}$. Z tej racji metodą krytyki okazuje się refleksja, która - jak zauważa Ludwig Landgrebe - ,niczego nie konstruuje, lecz tylko podnosi do świadomości tematycznej to, co zawsze już funkcjonowało nietematycznie i bezproblematycznie" ${ }^{\text {70 }}$. W fenomenologii nie można przyjmować żadnej nieprzebadanej podstawy poznania, a wszelkie przesądy powinny zostać rozpoznane. Skoro do istoty przesądu należy to, że jest on żywiony bezrefleksyjnie, przesąd przestaje być przesądem, gdy zostaje poddany refleksji i doprowadzony do jasnej świadomości (do oczywistości) ${ }^{71}$. Tak więc poddając refleksji przesądy, nie tylko rozpoznajemy ich właściwą naturę, lecz także uwalniamy się od nich.

\section{HERMENEUTYCZNE IMPLIKACJE KRYTYKI PRZESĄDÓW}

Zarówno Kant, jak i Husserl uznają wolność od przesądów za warunek samodzielnego myślenia. Dlatego celem filozofii krytycznej i fenomenologii jest uwolnienie poznającej świadomości od przesądów, określonych przez Kanta jako sądy przyjmowane bez zastanowienia, a przez Husserla - jako niejasności zrozumiałe same przez się. Według Kanta przesąd ma jednoznacznie negatywne konotacje i jego filozofia jest zorientowana na zwalczanie, a właściwie na unikanie przesądów. Natomiast Husserl rozróżnia przesądy w negatywnym i pozytywnym sensie, a celem fenomenologicznej krytyki poznania jest poddanie przesądów refleksji, skutkujące uwolnieniem od nich, zgodnie z zasadą, że przesąd poddany refleksji przestaje być przesądem. Kant w krytyce przesądów posiłkuje się metodą zawieszenia sądu, która ma charakter

68 Zob. E. Husserl, Zur phänomenologischen Reduktion, dz. cyt., 441.

69 Zob. P. Łaciak, Anonimowość jako granica poznania w fenomenologii Edmunda Husserla, Katowice 2012, 135-158.

70 L. Landgrebe, Faktizität als Grenze der Reflexion und die Frage des Glaubens, w: Tenże, Faktizität und Individuation. Studien zu den Grundfragen der Phänomenologie, Hamburg 1982, 123.

${ }^{71}$ Zob. S. Luft, dz. cyt., 61, 77-78. 
prewencyjny i stawia sobie za cel niedopuszczanie do ulegania przesądom, a Husserl stosuje metodę epoché w odniesieniu do niepoddanych refleksji niejasności, której celem jest sproblematyzowanie tego, co naturalnie samozrozumiałe i uczynienie go rzeczywiście zrozumiałym, przy czym w obu wypadkach chodzi o zawieszenie chwilowe, nie zaś stałe, aż do uczynienia tego, co problematyczne, zrozumiałym.

W odróżnieniu od Kanta, Husserlowska krytyka przesądów nie stanowi elementu teorii sądów, ponieważ przesądów nie można ograniczyć do wypowiedzi. Wszak teza nastawienia naturalnego, jako przesąd wszelkich przesądów, stanowi przesąd w tym znaczeniu, że nie ma w ogóle charakteru sądu, ale - jak zasygnalizowaliśmy we wcześniejszych rozważaniach - jest praprzeświadczeniem przed wydaniem wszelkiego sądu. Husserl dokonuje zarazem rehabilitacji przesądów, jako że samą generalną tezę nastawienia naturalnego można potraktować jako przesąd w pozytywnym znaczeniu, ściślej mówiąc: przed-sąd, to znaczy - jak zauważa Luft - to, co w naszym doświadczeniu założone, co nie jest czymś arbitralnym, lecz ma swą własną rację ${ }^{72}$. Rehabilitacja przesądów stanowi w istocie rehabilitację presumpcji implikowanej w przedwiedzy, ponieważ fenomenologia presumpcyjny charakter przedwiedzy podnosi do rangi przesądu w pozytywnym znaczeniu, czyli przed-sądu. Pod tym względem Husserlowska rehabilitacja przesądów wykazuje podobieństwo do Kantowskiej rehabilitacji presumpcji zawartej w mniemaniu, przy czym Kant, w odróżnieniu od Husserla, mniemanie utożsamia z sądem tymczasowym, odróżnionym od przesądu, tak że terminologicznie stanowiska Kanta i Husserla w kwestii przesądów są odmienne, ale rzeczowo - analogiczne. Tak więc w Husserlowskim pojęciu przesądu w pozytywnym sensie (przed-sądu) można doszukać się analogii do Kantowskiego pojęcia sądu tymczasowego, a fenomenologiczne pojęcie przesądu w negatywnym sensie, czyli w znaczeniu pomieszania tego, co presumpcyjne, z tym, co definitywnie pewne, stanowi odpowiednik Kantowskiego pojęcia przesądu.

Bez wątpienia rehabilitacja przesądów jest programowym hasłem hermeneutyki Hansa-Georga Gadamera. To właśnie Gadamer we współczesnej filozofii dokonuje rehabilitacji przesądów, kwestionując nie tylko

${ }^{72}$ Zob. Tamże, 61 (przypis 62). 
ich oświeceniową dyskredytację, lecz także racjonalistyczny (oświeceniowy) ideał poznania, rehabilitacji polegającej na tym, że przesądy nie muszą już oznaczać jedynie błędnych sądów. Zaznaczmy dobitnie, że Gadamerowska rehabilitacja przesądów pozostaje w analogii do Husserlowskiej rehabilitacji przedwiedzy, przy czym analogia ta jest nie tylko analogią rzeczową, lecz także terminologiczną, ponieważ Gadamerowskie przed-rozumienie, które ma charakter przesądu, a właściwie przed-sądu, nie jest niczym innym niż Husserlowską presumpcyjną, przed-sądową przedwiedzą ${ }^{73}$. Dodajmy, że Gadamerowska rehabilitacja przesądów oznacza w istocie powrót do źródłowego (prawniczego) znaczenia Vorurteil w sensie praejudicium, to znaczy jego dosłownego znaczenia jako Vor-Urteil (przed-sądu), wstępnego presumpcyjnego (antycypującego) rozstrzygnięcia czy mniemania, które pozostaje co do możliwości mniemaniem korygowalnym, i rozszerzenie tego znaczenia na sferę gnoseologiczną oraz aksjologiczną. Gadamer bowiem od przesądów fałszywych, ,przy których błędnie rozumiemy”, odróżnia przesądy prawdziwe, ,przy których rozumiemy"74, to znaczy przed-sądy (Vor-Urteile) w znaczeniu przed-rozumienia, warunkującego nasze rozumienie, zgodnie z zasadą, że ,opracowanie trafnych, adekwatnych do rzeczy projektów, które jako projekty są antycypacjami do potwierdzenia dopiero »na rzeczach «, jest stałym zadaniem rozumienia"75. W tym aspekcie Gadamer nawiązuje do Martina Heideggera, który twierdzi, że przed-rozumienie poprzedza rozumienie na zasadzie struktury antycypacji, a w konsekwencji nie jest możliwe bezzałożeniowe ujmowanie przedmiotu, bo wszelkie rozumienie porusza się zawsze już w kręgu wstępnego zasobu (Vorhabe) tego, co dane, wstępnego oglądu (Vorsicht), wstępnego pojęcia (Vorgriff), wstępnej opinii (Vor-Meinung) ${ }^{76}$.

73 Zaznaczmy, że S. Luft jedynie sygnalizuje, że Husserlowskie rozumienie przesądów jako przed-sądów, a w szczególności tezy nastawienia naturalnego jako absolutnego, stale potwierdzającego się przesądu, pozostaje w analogii do Gadamerowskiej rehabilitacji przesądów. Zob. Tamże.

${ }^{74}$ H.-G. Gadamer, Prawda i metoda. Zarys hermeneutyki filozoficznej, tłum. z niem. B. Baran, Kraków 1993, 284.

75 Tamże, 257.

76 Zob. M. Heidegger, Bycie i czas, tłum. z niem. B. Baran, Warszawa 1994, 213-215. 
Zdaniem samego Gadamera, zadaniem hermeneutyki jest „przyswojenie sobie własnych wstępnych mnieman i uprzedzeń", w przeciwnym razie nie byłoby możliwe odróżnienie przesądów prawdziwych od fałszywych, a „dominacja nie przejrzanych uprzedzeń czyni głuchym na rzecz przemawiającą w przekazie tradycji"' ${ }^{77}$. W odróżnieniu od Kanta i Husserla, Gadamer wskazuje wszechobecność przesądów w naszym poznaniu, twierdząc, że nie możemy się od nich uwolnić. Analogicznie do Husserla, Gadamer zaznacza jednak, że rozpoznanie przesądów jest możliwe dzięki ich zawieszeniu (zdystansowaniu się wobec nich): „Wyodrębnienie uprzedzenia jako takiego wymaga (...) zawieszenia jego obowiązywania"78, zawieszenia, które polega na problematyzacji tego, co bezwiednie uznajemy za samozrozumiałe, czemu w swym poznaniu i działaniu bezrefleksyjnie ulegamy, ponieważ „wszelkie (...) zawieszenie sądów, a wraz z tym i uprzedzeń, ma z logicznego punktu widzenia strukturę pytania" $"$.

Nie ulega wątpliwości, że Gadamerowskie pojęcie przed-rozumienia jest odpowiednikiem sądów tymczasowych Kanta i przedwiedzy Husserla. Można zatem zaryzykować tezę, że Gadamerowska rehabilitacja przed-rozumienia (w znaczeniu przed-sądu) pozostaje w analogii nie tylko do Husserlowskiej rehabilitacji przedwiedzy, lecz także Kantowskiej rehabilitacji presumpcyjnego mniemania. Tak więc różnica między Kantem, Husserlem i Gadamerem w tej kwestii pozostaje w dużym stopniu różnicą pojęciową, ponieważ pod względem rzeczowym można wskazać podobieństwa między tymi stanowiskami. Przeoczenie tej analogii skutkuje uproszczeniami, generującymi niewłaściwe interpretacje relacji między transcendentalizmem i hermeneutyką, a w szczególności relacji między fenomenologią i hermeneutyką, interpretacje, pomniejszające lub wręcz pomijające kluczowe znaczenie presumpcyjnego doświadczenia (czy mniemania) dla adekwatnego zrozumienia procesu poznania w filozofii Kanta i Husserla, a samą fenomenologię wpisujące jednoznacznie w paradygmat fundamentalizmu epistemologicznego, to znaczy preferujące dogmatyczne odczytanie Husserla, zgodnie z którym

\footnotetext{
77 H.-G. Gadamer, dz. cyt., 259.

78 Tamże, 284.

79 Tamże.
} 
adekwatna i apodyktyczna oczywistość ego cogito jest potraktowana jako archimedesowy punkt wyjścia filozofii.

\section{BIBLIOGRAFIA}

Aguirre A., Genetische Phänomenologie und Reduktion. Zur Letztbegründung der Wissenschaft aus der radikalen Skepsis im Denken E. Husserls, Martinus Nijhoff, Den Haag 1970.

Gadamer H.-G., Prawda i metoda. Zarys hermeneutyki filozoficznej, tłum. z niem. B. Baran, inter esse, Kraków 1993.

Godel R., Vorurteil-Anthropologie - Literatur. Der Vorurteilsdiskurs als Modus der Selbstaufklärung im 18. Jahrhundert, Max Niemeyer Verlag, Tübingen 2007.

Heidegger M., Bycie i czas, tłum. z niem. B. Baran, PWN, Warszawa 1994.

Husserl E., Die Krisis der europäischen Wissenschaften und die transzendentale Phänomenologie. Eine Einleitung in die phänomenologische Philosophie, hrsg. von W. Biemel, w: Husserliana, Gesammelte Werke, Bd. 6, Martinus Nijhoff, Den Haag 1962.

Husserl E., Doświadczenie $i$ sad. Badania nad genealogia logiki, tłum. z niem. B. Baran, Fundacja Aletheia, Warszawa 2013.

Husserl E., Idea fenomenologii. Pięć wykładów, tłum. z niem. J. Sidorek, PWN, Warszawa 1990.

Husserl E., Idee czystej fenomenologii i fenomenologicznej filozofii. Księga pierwsza, tłum. z niem. D. Gierulanka, PWN, Warszawa 1975. Husserl E., Kryzys nauk europejskich i fenomenologia transcendentalna, tłum. z niem. S. Walczewska, Wydawnictwo Rolewski, Toruń 1999. Husserl E., Logika formalna i logika transcendentalna. Próba krytyki rozumu logicznego, tłum. z niem. G. Sowinski, Wydawnictwo IFiS PAN, Warszawa 2011.

Husserl E., Phänomenologische Psychologie. Vorlesungen Sommersemester 1925, hrsg. von W. Biemel, w: Husserliana, Gesammelte Werke, Bd. 9, Martinus Nijhoff, Den Haag 1968.

Husserl E., Späte Texte über Zeitkonstitution (1929-1934). Die C-Manuskripte, hrsg. von D. Lohmar, w: Husserliana, Materialien, Bd. 8, Springer, Dordrecht 2006. 
Husserl E., Wybór pism, tłum. z niem. S. Walczewska, w: K. Święcicka, Husserl, Wiedza Powszechna, Warszawa 1993, 123-195.

Husserl E., Zur phänomenologischen Reduktion. Texte aus dem Nachlass (1926-1935), hrsg. von S. Luft, w: Husserliana, Gesammelte Werke, Bd. 34, Kluwer Academic Publishers, Dordrecht-Boston-London 2002.

Kant I., Antropologia w ujęciu pragmatycznym, tłum. z niem. E. Drzazgowska, P. Sosnowska, Wydawnictwo IFiS PAN, Warszawa 2005.

Kant I., Encyklopedia filozoficzna wraz z wyborem uwag o metafizyce i listów z lat 1769-1781, tłum. z niem. A. Banaszkiewicz, Aureus, Kraków 2003.

Kant I., Krytyka czystego rozumu, thum. z niem. R. Ingarden, Wydawnictwo ANTYK, Kęty 2001.

Kant I., Krytyka władzy sadzenia, tłum. z niem. J. Gałecki, PWN, Warszawa 2004.

Kant I., Logika. Podręcznik do wykładów, tłum. z niem. A. Banaszkiewicz, słowo/obraz terytoria, Gdańsk 2005.

Kant I., O odkryciu, po którym wszelka nowa krytyka czystego rozumu jest zbędna ze względu na istnienie wcześniejszej, tłum. z niem. Translatorium Filozofii Niemieckiej Instytutu Filozofii UMK pod kierunkiem M. Żelaznego, w: Tenże, Dzieła zebrane, t. 6: Pisma po roku 1781, red. M. Jankowski, T. Kupś, M. Marciniak, M. Żelazny, Wydawnictwo Naukowe UMK, Toruń 2012, 187-245.

Landgrebe L., Faktizität als Grenze der Reflexion und die Frage des Glaubens, w: Tenże, Faktizität und Individuation. Studien zu den Grundfragen der Phänomenologie, Felix Meiner Verlag, Hamburg 1982, 117-136.

Lohmar D., Erfahrung und kategoriales Denken. Hume, Kant und Husserl über vorprädikative Erfahrung und prädikative Erkenntnis, Springer-Science+Business Media, Dordrecht 1998.

Luft S., „Phänomenologie der Phänomenologie”. Systematik und Methodologie der Phänomenologie in der Auseinandersetzung zwischen Husserl und Fink, Kluwer Academic Publishers, DordrechtBoston-London 2002. 
Łaciak P., Anonimowość jako granica poznania $w$ fenomenologii Edmunda Husserla, Wydawnictwo Uniwersytetu Śląskiego, Katowice 2012.

Schneiders W., Aufklärung und Vorurteilskritik. Studien zur Geschichte der Vorurteilstheorie, frommann-holzboog Verlag, Stuttgart-Bad Cannstatt 1983.

Seebohm T., Die Bedingungen der Möglichkeit der Transzendental-Philosophie. Edmund Husserls transzendental-phänomenologischer Ansatz, dargestellt im Anschluss an seine Kant-Kritik, H. Bouvier u. Co. Verlag, Bonn 1962.

Shin G.H., Die Struktur des inneren Zeitbewußtseins. Eine Studie über den Begriff der Protention in den veröffentlichten Schriften Edmund Husserls, Verlag Peter Lang, Bern 1978.

Taguchi S., Das Problem des „Ur-Ich” bei Edmund Husserl. Die Frage nach der selbstverständlichen „Nähe” des Selbst, Springer, Dordrecht 2006.

\title{
THE CONCEPT OF PREJUDICE IN KANT'S CRITICAL PHILOSOPHY AND HUSSERL'S PHENOMENOLOGY
}

\begin{abstract}
This article examines the concept of prejudice (Vorurteil) in Kant's and Husserl's theories. According to Kant, prejudices must be distinguished from provisional judgments that may be called anticipations or maxims for all inquiry. We form a provisional judgment (vorläufiges Urteil) of a thing before we recognize it with definitive judgment (bestimmendes Urteil). Prejudices, by contrast, are provisional judgments (or opinions) wrongly taken as definitive judgments, namely judgments which are adopted as principles without research of the conditions of their truth. Thus, Kant's notion of prejudice has the negative connotations and the aim of the critical philosophy is to overcome all prejudices. In contrast to Kant, Husserl makes distinction between positive and negative prejudices: positive prejudice is understood as a pre-judgment (Vor-Urteil) in the form of presumptive pre-knowledge (Vorwissen) and corresponds to Kant's concept of anticipation belonging to provisional judgment, while objectivistic (naturalistic) naïveté appears to be negative prejudice. The aim of phenomenology is to suspend all prejudices and this suspension makes it possible to research of their origins. In the article author shows that Husserl's conception of prejudice as a pre-judgment is similar to Gadamer's rehabilitation of prejudice as a pre-understanding. Therefore, it is possible to indicate similarities between
\end{abstract}


Kant's concept of provisional judgment, Husserl's idea of pre-knowledge and Gadamer's conception of pre-understanding.

Keywords: Immanuel Kant, Edmund Husserl, Hans-Georg Gadamer, prejudice, pre-judgment, provisional judgment, pre-knowledge, pre-understanding 